\title{
416 マイクロローバーを搭載した火星探査機の概念設計
} Conceptual Design of Mars Probe with Micro Rover

\author{
○増田 紀昭（北大院） 正 戸谷 剛（北大工） \\ 正 永田 晴紀 （北大工） 正 工藤 勲（北大工） \\ Noriaki MASUDA ${ }^{1}$, Tsuyoshi TOTANI ${ }^{2}$, \\ Harunori NAGATA ${ }^{2}$ and Isao KUDO ${ }^{2}$ \\ 1: Graduate School of Engineering, Hokkaido University \\ Kita 13 Nishi 8, Sapporo 060-8628, Japan \\ 2: Department of Mechanical Science, Hokkaido University \\ Kita 13 Nishi 8, Sapporo 060-8628, Japan
}

Key Words: Space Equipment, Mars, Rover, Re entry

\section{1. 研究背景と目的}

旧ソ連のSputnik 1 号が初めて地球を周回する人工衛星と なって以来, 現在まで多数の衛星・探査機が打ち上げられて いる. 特に火星には 1975 年に打ち上げられた Viking, 1996 年に打ち上げられた Mars Global Surveyor や Mars Pathfinder などを含む多数の探査機が打ち上げられている 他, 将来は有人での火星探査も想定されており，依然として， 火星に対する関心は高いといえる。火星は，過去の探査によ って，30〜40 億年前，現在よりもはるかに温暖で，その表 層付近には大量の水が存在していたと考えられている他，そ の地層は Noachian, Hesperian, Amazonian と呼ばれる 3 種の時代に大別されると考えられており，各々の地域の推定 年齢が決定されている。しかし、近年打ち上げられた火星探 查機 Mars Global Surveyorによって得られたデータにより， これら推定年齢の正誤性に対する疑問が投げ掛けられてい る. そのため, 本研究では火星の地質学的年代をより正確に 調査することを目的とし, 断層地帯を側面から観測するため のマイクロローバーおよび, そのオ一ビターの設計を行って いる.

\section{2. 打ち上げ日時}

火星探查機の打ち上げに適した時期は約 780 日に一度訪 れることがこれまでの研究によって知られている(2). したが って，これらの条件と開発・製作期間を考慮し，本探查機の 打ち上げ日時は 2007 年 9 月 17 日, 到着日時は 2008 年 4 月 4 日，飛行時間は約 200 日と設定する。

\section{3. 突入カプセル火星 Re-entry}

\subsection{Re-entry 軌道}

先に述べたとおり，本探査機は地上での探査のためのマイ クロローバーを搭載している. よって, 火星周回軌道への到 達後，ローバーを搭載した突入カプセルを火星表面人着陸さ せるため, 火星大気圈内に Re-entry させる必要がある. 図 1 ，図 2 に突入力プセルの Re-entry 軌道を示す(3)(4). なおこ れらは, 高度 $300 \mathrm{~km}$ の軌道を周回するオービターから, 推 進剂により $0.1 \mathrm{~km} / \mathrm{s}$ の減速を与えられた突入カプセルが, 火星表面に到達するまでにとる軌道を示している。

\section{2 着地点誤差}

地球において, その大気密度は, 時間帯によって最大約 $50 \%$ のずれが生じることが知られている. 火星においても， 地球之同様，時間帯による密度のずれが生じることは十分に 想定される. そのため, 地球の場合と同様, 火星の大気密度 に最大約 $50 \%$ のずれが生じるものと仮定し, 軌道計算を行っ た。その結果を図 3 に示す.

この結果より, 密度が最も大きい場合と, 小さい場合とで は, 着地地点に約 $80 \mathrm{~km}$ の誤差が生じることがわかる.

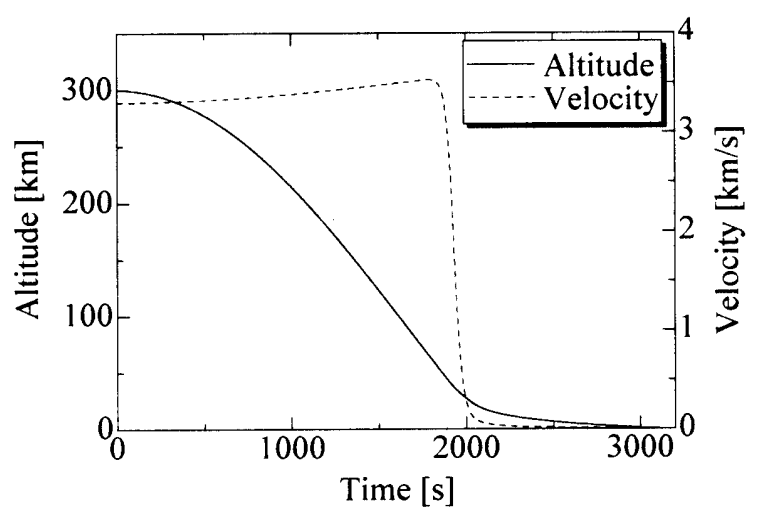

図 1. 突入カプセルの高度拉よび速度の時閒に対する変化

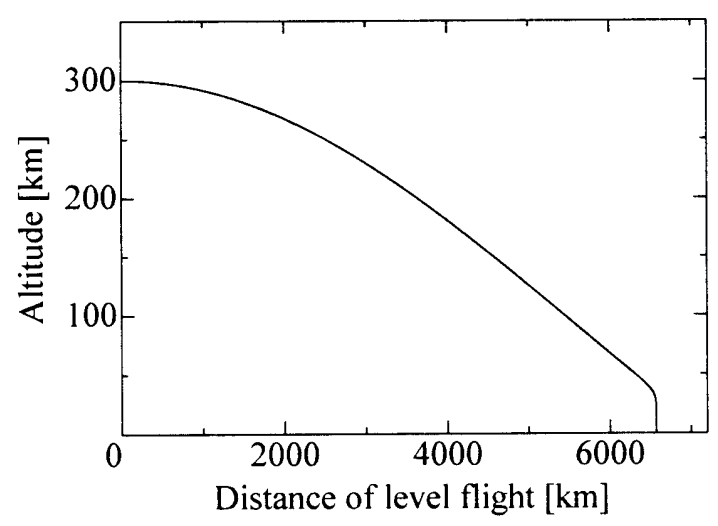

図 2. 突入カプセルの水平飛行距離と高度の関係

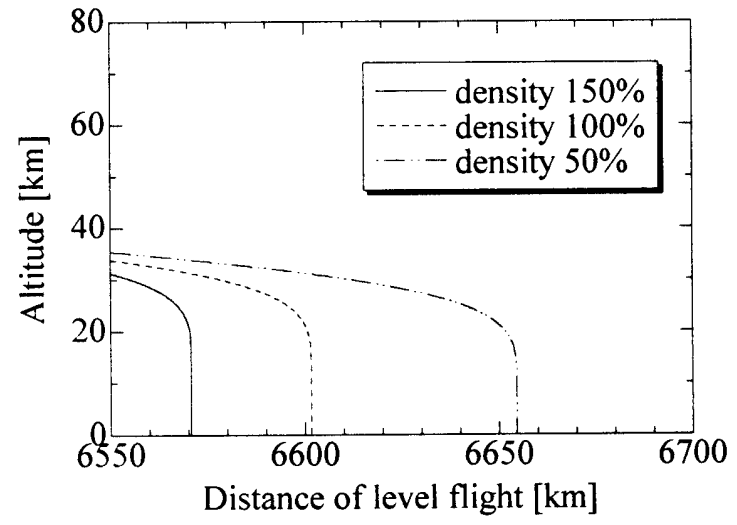

図 3. 異なる大気密度での水平飛行距離と高度の関係 


\section{3 突入時の熱制御}

大気圈突入時, 突入カプセルは大気との摩擦により多大な 熱を生じるため, 熱制御が必要不可欠である. よって, 突入 カプセルには安価であるアブレーション材による熱制御を 行うものとする.

アブレーション材は半無限固体であると想定し，その表面 は一定の熱流速 $q_{0}$ を受け，これによって融解·蒸発したアブ レーション材は表面から即座に剥離するものと仮定する。し たがって，固体表面は常に露出しており，固体表面温度が， 融解(または蒸発)温度 $\theta \mathrm{m}$ に等しいとすれば，一次元熱伝導 問題に理想化することが可能である．以上の条件の下におい て, 空力加熱量 $\mathrm{q}_{0}$, アブレーション速度 $u_{\mathrm{a}}$, アブレーショ ン材厚さ $\delta$ は以下の式で与えられる(5).

$$
\begin{aligned}
& q_{0}=1.84 \times 10^{+} V^{3} \sqrt{\frac{\rho}{r}} \\
& u_{a}=\frac{q_{0}}{\rho L\left[1+\frac{c\left(\theta_{m}-\theta_{x}\right)}{L}\right]} \\
& \delta=u_{a} \Delta t
\end{aligned}
$$

本研究では, アブレーション材として有能とされている, フェノール樹脂およびグラファイトの両面から計算を行っ た．その結果を表 1 に示す. なお，各材料の物性值は参考文 献(5),(6)の値を用いた.

表 1 から，グラファイトはフェノール樹脂に比べ，アブレ ーション材として有効であることがわかる．したがって，本 突入カプセルにはアブレーション材としてグラファイトを 採用することにした。

表 1 . 異なる材料での要求アブレーション材厚さ

\begin{tabular}{|c|c|}
\hline 材質 & 要求アブレーション材厚さ $[\mathrm{mm}]$ \\
\hline フェノール樹脂 & 29.73 \\
\hline グラファイト & 2.21 \\
\hline
\end{tabular}

\section{4. システムデザイン}

\section{1 探查機概要}

本探査機は，H-I A2022 での打ち上げを前提としている. そのサイズは約 $(\mathrm{H}) 4.4 \mathrm{~m} \times(\mathrm{W}) 1.5 \mathrm{~m} \times$ (D) $1.5 \mathrm{~m}$ である. 本探査機の主要緒元を表 2 に, 搭載している観測機器を表 3 に示す. 表 2 に示してあるとおり, 本探査機は地球周回軌道 脱出時には Solid Motor による軌道変換を行う。その後, Solid Motor 部は切り離され, 火星周回軌道への投入は Bipropellant Engineにより行うこととする.

\section{2 姿勢制御系の設計}

本探查機は, 突入カプセルとの分離の際などに複雑な姿勢 変更を行い, 高い精度の姿勢制御が要求される. そのため姿 勢制御方式としてはゼロモーメンタム方式の三軸制御 (Three-axis stabilization)を採用している。

\section{3 粠造設計}

本探査機の構造設計には 3 次元 $\mathrm{CAD}$ ソフトである Pro/ENGINEER を, 強度解析には解析ソフトである Pro/MECHANICA を用いた。

\section{4 ローバー概要}

本探査機に搭載するローバーの概念図を図 4 に示す.ロー バーサイズは太陽電池パネル展開時で, 約 $(\mathrm{H}) 0.85 \mathrm{~m} \times(\mathrm{W})$
$1.5 \mathrm{~m} \times$ (D) $0.7 \mathrm{~m}$ である. 本ローバーは凹凸が激しいと考 えられる断層地帯を探査するため, キャタピラによる走行を

\begin{tabular}{|c|c|c|}
\hline 探査機形状 & \multicolumn{2}{|c|}{ 箱型 } \\
\hline 探査機重量 & \multicolumn{2}{|c|}{$1.6 \times 10^{3} \mathrm{~kg}$} \\
\hline $\begin{array}{l}\text { 軌道変換用 } \\
\text { スラスター }\end{array}$ & $\begin{array}{c}\text { 地球周回軌道 } \\
\text { 脱出時 } \\
\text { Solid Motor } \\
\text { (PBAN/AL/AP) }\end{array}$ & $\begin{array}{c}\text { 火星周回軌道 } \\
\text { 投入時 } \\
\text { Bipropellant } \\
\text { Engine } \\
\left(\mathrm{N}_{2} \mathrm{O}_{4} / \mathrm{MMH}\right)\end{array}$ \\
\hline 姿勢制御方式 & \multicolumn{2}{|c|}{ 三軸制御(ゼロ・モーメンタム方式) } \\
\hline ランチャー & \multicolumn{2}{|c|}{ H- II A2022 } \\
\hline
\end{tabular}
行うこととする.

表 2. 探査機の主要緒元

表 3.観測機器

\begin{tabular}{|c|c|}
\hline Orbiter & Rover \\
\hline 熱放射分光計 & 小型熱放射分光計 \\
\hline $\begin{array}{c}\text { 高解像度 3 次元撮像 } \\
\text { カラーイメージャー }\end{array}$ & 小型ナビゲーションカメラ \\
\hline & レーザー距離測定器 \\
\hline
\end{tabular}

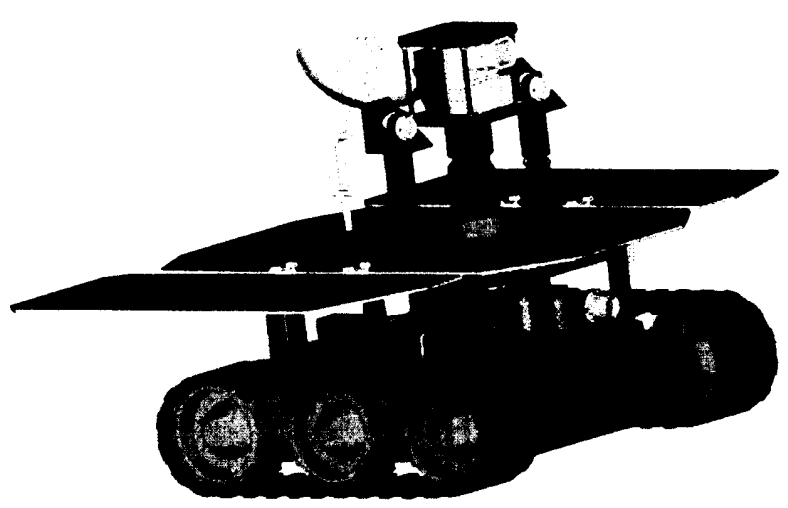

図 4. ローバー概念図

\section{5. 結論}

（1）着地点誤差について

時間帯による密度のずれにより着地点に比較的大き なずれが生じることが明らかになった，そのため，降 下中に高圧ガスなどの推進剤を噴射するなどの能動 的な措置をとる必要があり，更なる検討が必要である と考えられる。

(2) アブレーション材厚さについて 本突入カプセルは極少量のアブレーション材を用い るだけで，火星大気への Re·entry が可能であること が明らかとなった。

\section{参考文献}

（1）河島信樹 - 小池淳平, 図解一火星探査, PHP 研究所 (1997)

(2) Charles D. Brown, Spacecraft Mission Design Second Edition, AIAA, 1988

(3) Wilbur L. Hankey, Re-Entry Aerodynamics, AIAA, 1988

(4) John D. Anderson, Jr., Introduction to Flight Fourth Edition, Mc Graw Hill, 2000

（5）西川兼康・藤田恭伸, 伝熱学, 理工学社, 1982

（6）日本機械学会編，伝熱工学資料 改訂 4 版, 1986 